ROCZNIKI TEOLOGICZNE

Volume 65, issue 7 - 2018

Englis h version

DOI: http://dx.doi.org/10.18290/rt.2018.65.7-5en

\title{
ANGLICANS AND METHODISTS TOGETHER AGAIN? THE RESTORATION OF CHURCH UNITY BETWEEN ANGLICANS AND METHODISTS IN GREAT BRITAIN ACCORDING TO THE DOCUMENT MISSION AND MINISTRY IN COVENANT
}

\begin{abstract}
The article presents the latest proposal by the Church of England and Methodist Church Faith and Order bodies to restore Anglican-Methodist unity in Great Britain. If mutually adopted, the document titled Mission and Ministry in Covenant would enable the introduction of episcopacy in the British Methodist Church, the presbyteral ordination of Methodist ministers by a bishop, and - as a result - the mutual recognition and interchangeability of presbyteral ministry in both Churches. The proposal concerning the introduction of episcopal ordination in the Methodist Church recommends ordination to the episcopacy of each elected President of Methodist Conference. Thus ordained, the President-bishop would then ordain Methodist presbyters. As regards the Methodist presbyters who were not episcopally ordained, the document proposes the recognition of their ministry by the Church of England in the terms of "bearable anomaly." Yet, such a solution poses many questions and gives rise to theological doubts.
\end{abstract}

Keywords: Church of England; Methodist Church; Anglicans; Methodists; Covenant; Church unity; Mission and Ministry in Covenant.

\section{DIVISION AND THE ROAD TO UNITY}

After more than two centuries of division and after long and unsuccessful attempts to find unity, Anglicans and Methodists in Great Britain agreed to re-establish ecclesial communion. On 8 February 2018, the General Synod of the Church of England accepted by vote a document titled Mission and Ministry in Covenant, ${ }^{1}$ containing the rules of establishing unity while preserving

Rev. Przemystaw Kantyka, PhD, DSc, Assoc. Prof. (KUL) - Head of the Department of Protestant Theology in the Ecumenical Institute of the John Paul II Catholic University of Lublin; address for correspondence-e-mail address: kantyka@kul.pl

${ }^{1}$ The Church of England, The Methodist Church, Mission and Ministry in Covenant. Re- 
the independence of ecclesial organisms. The document had been prepared by the respective Faith and Order committees of the Church of England and the Methodist Church of Great Britain and concerns only these two church organisms. Three reasons for striving to restore ecclesial unity between Anglicans and Methodists were given: the Church is called to visible unity, so that the world can believe, seeing unity achieved in Christ; Methodism emerged as a movement within the Church of England, and therefore the restoration of ecclesial unity would be an act of healing and reconciliation; unification will make it possible to give more effective testimony and release new resources of energy for worship and evangelization. ${ }^{2}$

The separation of British Methodism from the parent Church of England took several decades; it effectively concluded with John Wesley's death and with the governance of Methodist associations being taken over by a group of one hundred elders (called the Legal Hundred). ${ }^{3}$ This is because John Wesley, just like his brother Charles, remained an Anglican priest until the end of his days. As long as Wesley lived, no formal act of separation of the British Methodists from the Church of England took place; neither was a parallel episcopal hierarchy organized. British Methodism remains a nonepiscopal denomination to this day, although debates are in progress on the possibility of introducing the episcopal office. In 1969 and 1972, the problems British Methodists have accepting episcopal ministry were the main cause behind the failure of the plan of organic union between the Church of England and the British Methodist Church. ${ }^{4}$

The more than two hundred years of separation left its mark on the life of both churches. Serious attempts to restore the broken unity started in the second half of the $20^{\text {th }}$ century. When preparing the current text of Mission and Ministry in Covenant, the Church of England and the Methodist Church of Great Britain drew on earlier documents of the Anglican-Methodist dialogue, ${ }^{5}$ but the theological foundations of the present document had already been developed in the 2003 Anglican-Methodist Covenant. ${ }^{6}$

port from The Faith and Order bodies of the Church of England and the Methodist Church, https://www.churchofengland.org/sites/default/files/2017-10/mission-and-ministry-in-covenant.pdf (accessed: 12.01.2018); henceforth abbreviated to MMC.

${ }^{2}$ MMC 19.

${ }^{3}$ Cf. Przemysław KAntyKa, Ku wspólnemu rozumieniu Kościoła. Eklezjologia dialogu katolicko-metodystycznego (Lublin: Wydawnictwo KUL, 2008), 15.

${ }^{4}$ Cf. Przemysław KANTYKa, "Metodyści," in Encyklopedia katolicka, vol. 12 (Lublin: TN KUL, 2008), col. 651 .

5 These documents were: Anglican-Methodist InTERnational Commission (AMIC), Sharing in The Apostolic Communion (Lake Junaluska, NC: World Methodist Council, 1996); ANGLICAN- 


\section{THE PINCIPLES OF THE COVENANT}

Mission and Ministry in Covenant contains two important proposals that, if accepted by the respective authorities of both churches, are meant to enable the mutual recognition and interchangeability of presbyteral ministry between them. This would mean restoring the relations that continued nearly until the end of the 18th century. The first proposal concerns establishing episcopal ministry in the Methodist Church, and the other one concerns the interchangeability of presbyteral/priestly ministry and the possibility of presbyters' ministry in both churches. This would be initiated through public declarations made by both churches. ${ }^{7}$ The mutual recognition of religious ministry is an inherent element of acknowledging the ecclesiality of both churches, which means it must not be excluded from the process of restoring unity. ${ }^{8}$ However, the new type of relations established by the adoption of the Covenant would not mean structural unity and would not abolish the distinct forms of church life in any way. ${ }^{9}$ Due to considerable differences in the understanding of diaconate, Mission and Ministry in Covenant does not contain references to this kind of ministry; there is only a statement that "a common understanding of the diaconate is not an essential requirement for the churches to enter into communion." Porvoo Declaration, ${ }^{11}$ establishing the communion of the Church of England and Nordic Lutheran churches: the interchangeability of ministries concerns episcopal and presbyteral ministry but not diaconal ministry. ${ }^{12}$

\subsection{THE ADOPTION OF EPISCOPAL MINISTRY BY THE METHODISTS}

For historical reasons, British Methodism still does not have episcopal ministry understood as the third level of holy orders - which means it does

Methodist International COMmission for Unity In Mission (AMICUM), Into All the World: Being and Becoming Apostolic Churches (London: Anglican Consultative Council, 2014).

${ }^{6}$ Anglican-Methodist Covenant, 2003, www.anglican-methodist.org.uk/cotc3.doc (accessed: 12.02.2018).

${ }^{7}$ MMC 11.

${ }^{8} \mathrm{MMC} 62$.

${ }^{9} \mathrm{MMC} 2$.

${ }^{10}$ MMC 15.

${ }^{11}$ Council for Christian Unity of the General Synod of the Church of England, The Porvoo Common Statement (London: Church House, 1993).

${ }^{12}$ MMC 16. 
not have what could be called a historical episcopate in apostolic succession. The current proposal is for Methodists to adopt a historical episcopate as a sign of the apostolic nature of their church. ${ }^{13}$ It is proposed that episcopal ministry should be embedded in the conference-connexional system existing in the Methodist Church ${ }^{14}$ in such a way that, without abolishing the current

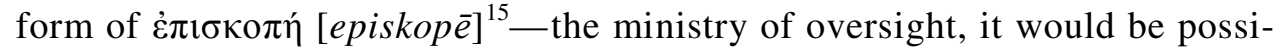
ble recognize it as a historical episcopate. ${ }^{16}$

Both in the Church of England and in the Methodist Church there is a strong sense of continuing the apostolic faith and mission. In the Church of England this continuation is ensured by the apostolic succession of bishops, ${ }^{17}$ while in the Methodist Church it is ensured through the corporate

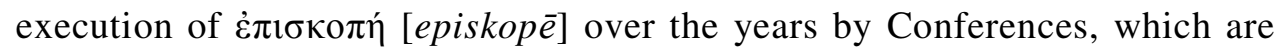
bodies conferring holy orders for religious ministry. ${ }^{18}$ According to the Anglican understanding, the historical episcopate is personal (i.e., exercised by a particular person ordained for this purpose), historical (in visible continuity over the centuries between the contemporary church and the church of the apostolic times), and received from the church (i.e., passed down by the universal church-in this sense, no church can initiate the existence of an episcopate de novo). ${ }^{19}$

Retaining the episcopate in the Church of England has been a subject of intense debates over the centuries; the most significant among them was the

\footnotetext{
${ }^{13}$ MMC 3, 14, 21.

${ }^{14}$ See: KANTYKA, Ku wspólnemu rozumieniu Kościoła, 45-51, 61-67.

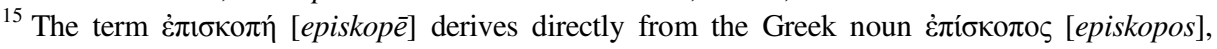
which means: (1) guardian; (2) overseer; (3) bishop. See: Remigiusz POPOWSKI, Stownik grecko--polski Nowego Testamentu (Warsaw: Vocatio, 1997), 126. Other meanings: (4) intelligencer; (5) controller. See Oktawiusz JuREwICZ, Słownik grecko-polski, vol. 1 (Warsaw: Wydawnictwo Szkolne PWN, 2000), 364. The word غ̇лıбколи́ [episkopē] should therefore be associated with pastoral care for the church and with the bishop having a ministerial authority to lead, oversee, and teach.

${ }^{16}$ MMC 4.

${ }^{17}$ A separately debated issue in ecumenical relations is the fact of the bishops of the Church of England actually having apostolic succession. The self-awareness of this church points to the existence of the apostolic succession of bishops in it. This awareness does not change by the fact that the Catholic Church refuses to recognize not only the apostolic succession of bishops but also the very validity of Anglican episcopal (and, consequently, other) holy orders. As far as the legal aspect of the issue is concerned, Pope Leo XIII's statement in the 1896 bull Apostolicae Curae, in which Anglican orders are referred to as invalid and null, remains in force to this day: "[...] aucoritate Nostra, motu proprio, certa scientia pronuntiamus et declaramus, ordinationes ritu Anglicano actas irritas prorsus fuisse et esse omninoque nullas." LEONIS PAPAE XIII Litterae apostolicae Apostolicae curae De Ordinationibus Anglicanis, AAS 29 (1896/97): 198-202; DS 3315-3319.

${ }^{18}$ MMC 22, 25, 31, 32, 34, 35.

${ }^{19}$ MMC 23.
} 
seventeenth-century debate known as the "anti-Puritan polemic." ${ }^{20}$ After long debates, it was decided that the episcopate would be preserved in its historical capacity; at the Chicago-Lambeth Conference of 1886-88, it was made part of the famous "Anglican Quadrilateral." ${ }^{, 1}$ Although according to the Anglicans having a historical episcopate is not a condition of the genuineness of the Church, it is nevertheless one of the four markers of its "Anglican character" identified on that occasion: "The Historic Episcopate, locally adapted in the methods of its administration to the varying needs of the nations and peoples called of God into the Unity of His Church." The expression "locally adapted" will make it possible to interpret the proposed Methodist episcopate in the Anglican spirit.

According to the new proposal, set out in Mission and Ministry in Covenant, "the Methodist Church has agreed to "consider afresh expressing the Conference's ministry of oversight in a personal form of connexional, episcopal ministry' and the Church of England has agreed to consider how it might 'recognise that ministry in the Methodist Church as a sign of continuity in faith, worship and mission in a church that is in the apostolic succession'.,"22 The prepared solution is meant to enable the Methodist Church to adopt a historical episcopate as a sign of its apostolic character without abandoning its way of management and its ecclesiology. The adoption of this sign of apostolic nature does not mean that the Methodist Church has not been part of the apostolic tradition before; it is only meant to stress this

${ }^{20}$ Cf. George TAVARD, The Quest for Catholicity: A Study in Anglicanism (London: Herder and Herder, 1964), 38-39.

${ }^{21}$ Lambeth Conference of 1888 (London: Wells Gardner, Darton \& Co., 1888), Resolution 11: "That, in the opinion of this Conference, the following Articles supply a basis on which approach may be by God's blessing made towards Home Reunion:

(a) The Holy Scriptures of the Old and New Testaments, as 'containing all things necessary to salvation,' and as being the rule and ultimate standard of faith.

(b) The Apostles' Creed, as the Baptismal Symbol; and the Nicene Creed, as the sufficient statement of the Christian faith.

(c) The two Sacraments ordained by Christ Himself-Baptism and the Supper of the Lordministered with unfailing use of Christ's words of Institution, and of the elements ordained by Him.

(d) The Historic Episcopate, locally adapted in the methods of its administration to the varying needs of the nations and peoples called of God into the Unity of His Church."

According to Reginald H. Fuller, the point concerning the episcopate was the most controversial one in the famous declaration of the 1888 Lambeth Conference (known as the Chicago-Lambeth Qadrilateral). Reginald H. FULLER, “Anglican Self-Understanding and Anglican Traditions,” in Tradition im Luthertum und Anglikanismus, ed. Günther Gassmann and Vilmos Vajta (Oecumenica, 1971/72 (Gütersloh: Gütersloher Verlagshaus Gerd Mohn, 1972), 185.

${ }^{22}$ MMC 25. 
fact, since being part of the apostolic tradition consists, among other things, in passing on the responsibility involved in religious ministry. The historical episcopate is understood here as a sign rather than a guarantee of the continuity and unity of the church, because it is not understood by the Methodists as part of the essence of faithfully performed religious ministry. ${ }^{23}$

Having episcopal ministry is not a new thing in Methodist Churches outside Great Britain. Various offshoots of Methodism in America and elsewhere in the world do have bishops, the theology of ministry may be understood in different ways in different churches. Moreover, by adopting the historical episcopate as a sign, the British Methodists are not taking on the obligation to ensure that episcopal ministry is understood and performed exactly as it is in the Church of England. ${ }^{24}$ But this is not a problem, becauseas noted above-one of the four markers of Anglican identity allows having a historical episcopate "locally adapted in the methods of its administration to the varying needs of the nations and peoples." Such differences already exist between Anglican Churches in the world, which is a clear example of the applied principle of comprehensiveness,${ }^{25}$ thanks to which divergent theological interpretations do not damage ecclesial unity. This principle has already been used in creating the Porvoo Communion of Churches. ${ }^{26}$

In practice, the adoption of episcopal ministry by the British Methodists would consist in ordaining the President of the Conference-who has invariably been a presbyter so far-to the episcopal level. He would be the one to celebrate the conference Eucharist and to chair the session of presbyters, as well as the one to ordain the candidates recommended by the Conference. Therefore, what the parties engaged in dialogue deemed the most appropriate was that, each time, the President of the Conference should be ordained bishop. Thus, the Methodist Church would still be independent in its pastoral ministry of care and oversight through the Conference system, and the bishop would always hold his office in a personal and connexional form at the same time, always conferring the holy orders, which no other representative of the Conference would be authorized to do. ${ }^{27}$ The elected President of the Conference would be ordained by the bishops of partner

${ }^{23}$ MMC 25-27.

${ }^{24} \mathrm{MMC} 30$.

${ }^{25}$ Comprehension - understanding for and tolerance of different views; comprehensive - understanding, receptive, extensive; comprehensiveness - in Anglican theology, this term means the ability to combine and understand different views, even extreme or contrary ones.

${ }^{26}$ MMC 30.

${ }^{27}$ MMC 36-38, 42-43. 
churches, in which orders are recognized by the parties to the dialogue, in accordance with the canon of the Council of Nicaea, stating that the new bishop is to be ordained by at least three other bishops. ${ }^{28}$

In accordance with the current practice, the President-Bishop would be elected for one year at first, but his time in office may be specified differently in the future. The President's episcopal ministry would be permanent and would comprise all the duties currently fulfilled by the President, which include officiating ordination rites. ${ }^{29}$ The first episcopal orders would be conferred on the President of the Conference by bishops of churches having historical episcopates, in accordance with the Methodist form agreed on by the ecumenical partners. In subsequent years, the minimum necessary to confer holy orders would be ensured in the same way as long as this is necessary, but mutual invitation of Anglican and Methodist bishops to participate in episcopal ordination should be made permanent practice. ${ }^{30}$ The solutions presented in Mission and Ministry in Covenant are meant to lead to achieving the goal, which is to pass on episcopal ministry to the Methodists while preserving the connexion and conference system they have developed. In this way, the model of "unity in reconciled diversity" 31 would be put into practice.

\subsection{THE INTERCHANGEABILITY OF PRESB YTERAL/PRIESTLY MINISTRY}

While the Methodist Church recognizes as valid the presbyteral ordination conferred in the Church of England, the Anglicans have not, so far, recognized the orders conferred in the Methodist Church without a bishop but merely by the President of the Conference, who was a presbyter. There

\footnotetext{
${ }^{28}$ MMC 41. Council of Nicaea, Canon 4: "It is by all means proper that a bishop should be appointed by all the bishops in the province; but should this be difficult, either on account of urgent necessity or because of distance, three at least should meet together, and the suffrages of the absent [bishops] also being given and communicated in writing, then the ordination should take place. But in every province the ratification of what is done should be left to the Metropolitan"; as cited at: New Advent (website), http://www.newadvent.org/fathers/3801.htm (accessed: 20.01.2018).

${ }^{29}$ MMC 43.

${ }^{30}$ MMC 44.

${ }^{31}$ For information on the models of unity, see: Stanisław Celestyn NAPIÓRKOwSKI, "Modele jedności," in Ku chrześcijaństwu jutra. Wprowadzenie do ekumenizmu, ed. Wacław Hryniewicz, Jan Sergiusz Gajek, Stanisław Józef Koza (Lublin: TN KUL, 1996), 479-503.
} 
are also further differences. In Anglicanism, an understanding of holy orders (ordination) as a sacramental act is still present, though ordination is not explicitly referred to as a sacrament. Moreover, in the Church of England there is no practice of entrusting a deacon or a person without any kind of holy orders with officiating the Eucharist, which-on an exceptional basis - has sometimes been done in the Methodist Church. ${ }^{32}$

The proposals presented in Mission and Ministry in Covenant are aimed at creating a situation in which all Anglican and Methodist presbyters/priests could minister in both Churches. ${ }^{33}$ The proposed solutions go in the direction of making the pattern of ordination and religious ministry in the Methodist Church similar to that which is known in the Church of England. Still, introducing the ordination of Methodist presbyters by the President of the Conference, who would have episcopal orders after the document has entered into force, only solves the problem of newly ordained presbyters. Presbyters ordained without a bishop have not, so far, been permitted to minister in the Church of England. Mission and Ministry in Covenant proposes the interchangeable ministry of all presbyters of the two churches. ${ }^{34}$

In this situation, how is it possible to induce the Church of England against its previous practice to recognize the ministry of Methodist presbyters ordained without a bishop before the new resolutions entered into force? The formula invoked in this case is that of "temporary bearable anomaly," a concept present in Anglican theological thought. This formula means bearing a particular irregularity for a specified period of time, for the sake of protecting a higher-order good-in this case, ecclesial unity. ${ }^{35}$ The requirement for Methodist clergymen to be ordained again, this time by a bishop, could be unacceptable to the Methodists; besides, it would question the validity of their previous orders and would make the situation too similar to the Anglican-Roman Catholic relations. By contrast, the Anglicans' decision to tolerate the anomaly of accepting Methodist clergy ordained by a presbyter instead of a bishop will, in fact, make it possible to remove a much more serious anomaly: the lack of unity in church life. ${ }^{36}$ Because the aim of the unification document is to convince not only the church authorities but also, if possible, all the clergy and laity of both churches to accept the solutions

\footnotetext{
${ }^{32}$ MMC 48. See: KANTYKA, Ku wspólnemu rozumieniu Kościoła, 147.

${ }^{33}$ MMC 3, 13-14, 45.

${ }^{34}$ MMC 54.

${ }^{35}$ MMC 5, 56.

${ }^{36}$ MMC 57-58, 60.
} 
adopted, the existing precedents were invoked. They had been discussed as early as the sixteenth century by the Anglican theologian Richard Hooker, who believed that when the church is in great need and has no other choice, God Himself replaces a bishop during ordination. It was therefore presumed in Mission and Ministry in Covenant that "it might be said that Hooker considers non-episcopal ordination as an anomaly, certainly, but as one that has been and can be carried on its journey through history by the church of God, because non-episcopal ordinations may be recognised in appropriate circumstances as "effectual'." ${ }^{37}$ Although this mental construct may seem logically and legally dubious to a reader accustomed to the Roman Catholic canon law, we must remember that this solution is meant to convince Anglicans, not Catholics, to accept the proposal of recognizing the earlier Methodist holy orders as valid. Other precedents that have been cited refer to the formation of the united churches in India, which Anglican Churches joined together with other denominations in order to create new ecclesial organisms. The Church of South India (in 1947) and the Church of North India (in 1970) were made up of the Anglican Church and non-episcopal churches. In the former case, the validity of the orders of all clergy was acknowledged with a single act; in the latter case, a decision was made to perform a collective imposition of hands by bishops on the clergy from non-episcopal churches during the inaugural service in order to complement the holy orders for those who had not been episcopally ordained. ${ }^{38}$

It seems that the argument which is supposed to prevail and ensure the acceptance of the solution consisting in allowing a "bearable anomaly" in the form of accepting Methodist clergy not ordained by a bishop is the argument from church unity. In this case, unity is a higher value than avoiding the "anomaly" involved in the issue of presbyteral ordination. ${ }^{39}$ An additional argument was also proposed in the form of recognizing the relationship established between the presbyter and the bishop in the act of ordination as equivalent to the relationship that consists in remaining in ecclesial communion with a bishop or-to use the Methodist expression-in connexion with him. In this way, by accepting the ministry of Methodist presbyters,

\footnotetext{
${ }^{37}$ MMC 63. The passage from Richard Hooker's Laws of Ecclesiastical Polity VII.xiv,11 is provided as cited in: Norman SYKeS, Old Priests and New Presbyter: The Anglican Attitude to Episcopacy, Presbyterianism and Papacy since the Reformation (Cambridge: University Press, 1956), 70-71.

${ }^{38}$ MMC 69.

${ }^{39}$ MMC 65.
} 
Anglican bishops would be accepting them as being in communion with a different bishop, with whom the bishop accepting them is in communion. The apostolic nature of the church would be thus manifested. ${ }^{40}$

\section{THE REMAINING QUESTIONS AND DOUBTS}

The application of the "bearable anomaly" or "tolerable irregularity" principle recommended in Mission and Ministry in Covenant provokes questions about the limits of its application as well as about its scope in theology and canon law. In the Catholic Church there are ways of dealing with formal errors in administering the sacraments. The application scope of the "bearable anomaly" principle, however, goes far beyond the use of the Ecclesia supplet iurisdictionem or sanatio in radice principles in the Catholic Church. The first of these principles refers to the possibility for the Church to make up for the formal deficiencies that occurred, but on the condition that the essence of sacramental action is retained. Thus, the Church may, for instance, "make up for" the formal lack of a validly ordained priest's jurisdiction to give absolution, but this is not possible in the case of the lack of valid orders. Another way of fixing a legal error known in the Catholic Church is sanatio in radice-used, for example, when a formal deficiency results in a legal action being invalid. It is possible to validate only that action which would be valid if there was no legal deficiency. ${ }^{41}$

The phrasing of the principle of the Church of England recognizing Methodist orders conferred without a bishop being present as a "bearable anomaly" can be seen as waving aside the essence of holy orders. If ordination performed by a bishop in apostolic succession is so important to the Church of England that the document Mission and Ministry in Covenant contains an article introducing this kind of ordination in the Methodist Church, then even though tolerating the lack of orders conferred in this way in Methodist clergy previously ordained without a bishop's ministry involved can be regarded as a gesture of Anglicans towards the Methodists, it is still

\footnotetext{
${ }^{40}$ MMC 67-68.

${ }^{41}$ A typical example of sanatio in radice applied in practice is the situation when the Roman Rota issues a decree acknowledging the validity of a marriage that was not validly entered into not due to what is called a diriment impediment but due to the cleric's lack of competence to officially assist during the contraction of a particular marriage. See: Piotr M. GAJDA, Prawo matżeńskie Kościoła katolickiego, https://opoka.org.pl/biblioteka/T/TA/TAI/pr_malzenskie_10.html (accessed: 13.02.2018).
} 
an attempt to attain unity without solid theological foundations. Theologians representing both parties did not try hard enough to find a more theologically sound solution, and referring to previously ordained Methodist clergy as a "bearable anomaly" may be offensive to them. The entire construction is a way of dealing with the problem by taking a shortcut and waiting until, with time, all the Methodist clergy are ministers ordained by bishops.

The document does not directly address the issue of recognizing the validity of Methodist orders conferred without a bishop; it assumes that a church act will be issued approving the ministry of Methodist clergy thus ordained as equivalent to the ministry of Anglican clergy ordained by bishops. If ordination is a church act (i.e., a church determines its rite and object and confers orders), there remains the question of whether another church act can declaratively acknowledge the validity and completeness of orders conferred in accordance with different rules. The answer to this question, not asked directly in Mission and Ministry in Covenant, is positive if the document proposes this procedure, though limited in time to the end of the life of the last Methodist clergyman ordained by the President of the Conference instead of by a bishop.

It transpires that, for the contemporary Church of England, it is theologically problematic to elaborate the theological justification of presbyteral orders, which was done by the founder of Methodism, John Wesley. ${ }^{42}$ What could also be helpful is reaching into the history of the Church before the sixteenth-century Reformation. Until that time, the Catholic Church allowed presbyteral orders on a dispensation basis, which means it regarded this as theologically possible. Authorization to ordain the brothers in his order would usually be granted to a territorial abbot, who was not a bishop. Although after the Council of Trent this form of ordination was abandoned, the validity of the orders previously conferred in this way was never questioned. ${ }^{43}$

${ }^{42}$ Cf. KantyKa, Ku wspólnemu rozumieniu Kościoła, 165.

43 "With his bull Sacra Religionis of 1 February 1400, Pope Boniface IX (1389-1404) authorized the abbot of Sts Peter and Paul Monastery and St. Osita in Essex, England - the abbot himself and his successors - to confer minor holy orders as well as major holy orders, including presbyterate, on their spiritual votaries (monks who have taken vows): omnes minores, necnon subdiaconatus, diaconatus et presbyteratus ordines statutis a iure temporibus conferre libere et licite valeat. "[...] With his bull Gerentes ad vos, dated 16 November 1427, Pope Martin V (1417-1431) granted five-year authorization to the abbot of the Cistercian monastery in Altzelle, Meissen diocese, to confer all minor and major holy orders, including presbyterate"; translated from: Marian PASTUSZKO, "Szafarz święceń (kanony 1012-1023)," Prawo Kanoniczne 43, nos. 3-4 (2000): 125-126 [“Papież Bonifacy IX (1389- 
By "mending" the Methodist orders, the document brings the united Anglicans and Methodists closer to the Catholic Church and Orthodox Churches in terms of the way of conferring presbyteral and episcopal orders. It does not, however, mention the subject of ordination: it ignores the issue of allowing women to receive major holy orders. Therefore, despite the doctrine of ordination becoming closer to Catholicism and the Orthodox Church, this issue will continue to divide our churches.

Another issue is the application of the theological conception allowing the existence of a "bearable anomaly" or "tolerable irregularity" in an effort to meet the Anglican theological sensitivity. Mission and Ministry in Covenant in fact contains methods of "mending" the Methodist ministries and adjusting them to the requirements of the Church of England, thus in a way imposing Anglican solutions on the Methodists. The General Synod of the Church of England has already decided to approve the document and to put the solutions proposed in it into practice. ${ }^{44}$ Response from the Methodist Church is expected. It is known that small church communities are highly sensitive to stronger partners' attempts at enforcing changes in their doctrine and ecclesial life. Despite the disproportion in terms of numbers that results in their weaker position, will the Methodists be willing to accept the reduction of their already ordained and ministering clergy to the role of a "bearable anomaly"? Will they recognize the need to possess the historical episcopate as a sign if they have felt no such need for 200 years or even clearly refused to accept this kind of solution?

\section{CONCLUSION}

Undoubtedly, even if it is limited to the British context for the time being, the pursuit of ecclesial unity between Anglicans and Methodists is the right

\footnotetext{
1404) bullą Sacra religionis z 1 lutego 1400 r. udzielił uprawnienia Opatowi klasztoru Piotra i Pawła oraz św. Osity w Essex, w Anglii, aby on sam i jego następcy swoim duchownym profesom (zakonnikom po ślubach) udzielali święceń niższych, a także wyższych, nie wyłączając prezbiteratu: omnes minores, necnon subdiaconatus, diaconatus et presbyteratus ordines statutis a iure temporibus conferre libere et licite valeat. [...] Papież Marcin V (1417-1431) bullą Gerentes ad vos z dnia 16 listopada 1427 r. udzielił uprawnienia na okres pięciu lat opatowi klasztoru cystersów w Altzelle, w diecezji Meissen, aby mógł on udzielać wszystkich święceń niższych i wyższych włącznie z prezbiteratem.”]

44 "General Synod: Mission and Ministry in Covenant. Church of England moves a step closer towards union with the Methodists," https://www.churchtimes.co.uk/articles/2018/16-february/news/ uk/general-synod-mission-and-ministry-in-covenant (accessed: 16.02.2018).
} 
an ecumenically desirable thing. In this case, the restoration of unity resembles the return of the once unwanted Methodist sons and daughters to the Anglican home. In the situation of unceasing divisions in churches that emerged as a result of the sixteenth-century Reformation, every step taken towards unity should be regarded as the right direction. To be lasting, however, unity must be accepted by the entities concerned as well as based on solid theological foundations. One cannot help the impression that the document titled Mission and Ministry in Covenant would need a more thorough theological background to be regarded as a theological rock- a foundation not to be invalidated.

In conclusion, it is necessary to return once more to the ecumenical implications of the Anglican-Methodist covenant. It is worth asking a question that has to remain unanswered for now (at least until the AnglicanMethodist covenant becomes actual practice): to what extent will the adopted solutions facilitate or perhaps complicate the dialogue of the Anglicans and the Methodists with the Catholic Church? Moreover: can the theological formula of allowing "bearable anomaly" be used also in the case of other Churches and religious communities seeking unity? Finally: is it legitimate to hope that the united Anglicans and Methodists will not be satisfied with the status quo but will together embark on the effort of restoring the universal visible unity of Christ's Church?

\section{BIBLIOGRAPHY}

"Anglican-Methodist Covenant" (2003), www.anglican-methodist.org.uk/cotc3.doc (accessed: 12.02.2018).

ANGLiCAN-Methodist InTERnATIONAL COMmission FOR Unity in Mission. Into All the World: Being and Becoming Apostolic Churches. London: Anglican Consultative Council, 2014.

Anglican-Methodist International Commission. Sharing in The Apostolic Communion. Lake Junaluska, NC: World Methodist Council, 1996.

Council for Christian Unity of the General Synod of the Church of England. The Porvoo Common Statement. London: Church House, 1993.

First Council of NiCAEA. "The Canons.” New Advent (website), http://www.newadvent.org /fathers/3801.htm (accessed: 20.01.2018).

Fuller, Reginald H. "Anglican Self-Understanding and Anglican Traditions." In Tradition im Luthertum und Anglikanismus, edited by Günther Gassmann and Vilmos Vajta (Oecumenica, 1971/72), 175-190. Gütersloh: Gütersloher Verlagshaus Gerd Mohn, 1972.

Gajda, Piotr M. Prawo matżeńskie Kościoła katolickiego [Marriage law of the Catholic Church], https://opoka.org.pl/biblioteka/T/TA/ TAI/pr_malzenskie_10.html (accessed: 13.02.2018). 
"General Synod: Mission and Ministry in Covenant. Church of England moves a step closer towards union with the Methodists," https://www.churchtimes.co.uk/articles/2018/16-february/news/uk/ general-synod-mission-and-ministry-in-covenant (accessed: 16.02.2018).

KANTYKA, Przemysław. Ku wspólnemu rozumieniu Kościoła. Eklezjologia dialogu katolicko-metodystycznego [Towards a common understanding of the Church. The ecclesiology of CatholicMethodist dialogue]. Lublin: Wydawnictwo KUL, 2008.

KantYka, Przemysław. "Metodyści" [Methodists]. In Encyklopedia katolicka [The Catholic encyclopedia], vol. 12, col. 651-655. Lublin: TN KUL, 2008.

Lambeth Conference of 1888. London: Wells Gardner, Darton \& Co., 1888.

LeONIS PAPAE XIII Litterae Apostolicae Apostolicae curae De ordinationibus Anglicanis. AAS 29 (1896/97): 198-202.

NAPIÓRKowsKI, Stanisław Celestyn. "Modele jedności” [Models of unity]. In Ku chrześcijaństwu jutra. Wprowadzenie do ekumenizmu [Towards the Christianity of tomorrow: An introduction to ecumenism], edited by Wacław Hryniewicz, Jan Sergiusz Gajek, and Stanisław Józef Koza, 479-503. Lublin: TN KUL, 1996.

Pastuszko, Marian. "Szafarz święceń" [Dispenser of holy orders] (canons 1012-1023). Prawo Kanoniczne 43, nos. 3-4 (2000): 117-251.

SyKes, Norman. Old Priests and New Presbyter: The Anglican Attitude to Episcopacy, Presbyterianism and Papacy since the Reformation. Cambridge: University Press, 1956.

TAVARD, George. The Quest for Catholicity: A Study in Anglicanism. London: Herder, 1964, 38-39.

The Church of England, The Methodist Church. Mission and Ministry in Covenant. Report from The Faith and Order bodies of the Church of England and the Methodist Church, https://www.churchofengland.org/sites/default/files/2017-10/mission-and-ministry-in-covenant. pdf (accessed: 12.01.2018).

\section{Translated by Piotr Czyżewski}

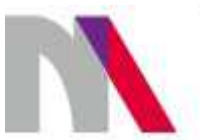

The preparation of the English version of Roczniki Teologiczne (Annals of Theology) and its publication in electronic databases was financed under contract no. 836/P-DUN/2018 from the resources of the Minister of Science and Higher Education for the popularization of science. 